19.

\title{
„PRIDNE SLOVENSKE SLUŽKINJE“- POVIJEST SLOVENSKIH RADNICA U ZAGREBU IZMEĐU DVAJU SVJETSKIH RATOVA
}

\section{Barbara Riman}

UDK: 331.1-055.2(497.5 Zagreb=163.6)“192/193“

Izvorni znanstveni članak

Sažetak: Na hrvatskim je prostorima, u različitim povijesnim razdobljima, živio i veći broj Slovenaca. Promatrajući popise stanovništva, vidljivo je da postoji spolna nejednakost među članovima slovenske zajednice u Hrvatskoj koja je prisutna tijekom cijelog 20. stoljeća. Jedni od ključnih razloga prisutnosti velikog broja Slovenki na prostoru Hrvatske jesu oni ekonomski. Djevojke i žene dolazile su u hrvatske industrijske centre u potrazi za poslom, a u razdoblju između dvaju svjetskih ratova upravo je Zagreb imao poseban položaj. Mogao je ponuditi dovoljno širok spektar zaposlenja kako bi žene, koje nisu imale drugog izbora u svojem slovenskom zavičaju, mogle pronaći posao i riješiti egzistencijalne probleme. One koje su dolazile u potrazi za poslom iskazale su se kao dobre radnice. Ovaj rad želi ukazati na temu koja se do sada nije obrađivala u hrvatskoj i slovenskoj historiografiji, a odnosi se na život slovenskih radnica u Zagrebu u spomenutom periodu.

Ključne riječi: ženske migracije, ekonomske migracije, Zagreb, djevojačka društva, Slovenke u Hrvatskoj, kućne pomoćnice

\section{UVOD}

$\sqrt{\square}$ igracije stanovništva prisutne su od kada postoje ljudi. Seljenja se pojavljuju i postoje tijekom cijele povijesti u različitim intervalima, različitim intenzitetima i iz različitih oni prvi uvijek bili vidljiviji.

Naime, kada se spominju migranti, onda se pojavljuje slika mladog muškog industrijskog radnika, koji je regrutiran za rad predviđen upravo za muškarce. ${ }^{1}$ No, u tim su mi-

$\overline{1}$ Mirjana Morokvašić, „Gendering Migration“, Migracije i etničke teme, 30/2014., br. 3, 360. 
gracijama postojale i žene, često neprimijećene jer su uglavnom bile vezane za kućne poslove i djecu. Može se tvrditi da su u tim proučavanjima migracija na određen način bile i marginalizirane te se o njima i njihovoj problematici istraživalo i pisalo rijetko. Ako su i postojale samohrane majke, koje su radile kao domaćice, sluškinje i guvernante, taj je njihov rad bilo teško opaziti jer je to uglavnom bio posao koji se obavljao u kući i od kuće. Muški je rad široj javnosti bio vidljiviji. Istraživači su migrantkinje uglavnom vidjeli kao osobe koje odlaze radi ujedinjavanja obitelji ${ }^{2}$ i zapravo ih se promatralo kroz prizmu uzdržavanog člana obitelji.

Kada se u te ženske migracije uvrste i one s prostora Slovenije, onda je potrebno napomenuti da se u odnosu na države nekadašnje Jugoslavije, pa tako i Hrvatske, vidi određena razlika. Istraživanja su pokazala da su među migrantima s područja nekadašnje Jugoslavije žene i muškarci bili gotovo podjednako zastupljeni, ali s određenim iznimkama. Tako su muškarci prevladavali među iseljenim Hrvatima i Makedoncima, a žene migrantkinje bile su znatno brojnije među slovenskim iseljenicima. ${ }^{3}$

Tematika ženskih migracija u slovenskim znanstvenim krugovima nije u potpunosti nepoznata. Ipak, tu su problematiku prije svega promatrali kroz prizmu Aleksandrinki ${ }^{4} \mathrm{i}$ Šavrinki ${ }^{5}$ te života i rada djevojaka u drugim europskim državama ${ }^{6}$ i Americi. ${ }^{7}$ Nažalost, o ženama i djevojkama koje su dolazile u Hrvatsku ili na prostor nekadašnje Jugoslavije istraživalo se i pisalo malo. Promatralo ih se u kontekstu migracija uopće i u tematskim cjelinama povezanima s njihovim muškim kolegama. Usputno je spomenuta problematika sezonskih migrantkinja na državnom posjedu Belje u Baranji. Izuzetak je rad o slovenskim kućnim pomoćnicama u Beogradu. ${ }^{8}$

O Slovenkama u Hrvatskoj, razlozima doseljavanja i njihovu položaju nije se mnogo istraživalo. ${ }^{9}$ Ovdje se čini važnim spomenuti rad Filipa Škiljana, koji djelomično odgovara na pitanje što znače Slovenke u Hrvatskoj, ali i zašto se pokazala potreba da se o njima istražuje i piše.

Ako pretpostavimo da ih je samo 10000 (Slovenki - op. a.) doista radilo u hrvatskim građanskim obiteljima, i da je u određenom razdoblju (...) u svakoj od tih obitelji bilo prosječno dvoje male djece, tada moramo reći da su (...) slovenske sluškinje u Hrvatskoj, potpuno nepripremljene za tu funkciju, sudjelovale u odgoju 20000 hrvatske djece u najosjetljivijoj

2 Sanja Cukut Krilić, Spol in migracija: izkušnje žensk kot akterk migracij, Ljubljana 2009., 43.

3 M. Моrokvašrć, „Feminizacija migracija?“", Stanovništvo, 2/2010., 37.

4 Daša Koprivec, Dedišcina aleksandrink in spomini njihovih potomcev, Ljubljana 2013.; Darja SKrт, Aleksandrinke, Ljubljana 2014.; Stazica Zorn i Inga MikLavčič-BreZigar (ur.), Aleksandrinke iz Renč, Ljubljana 2015.

5 Špela Ledinek Lozej i Nataša Rogelja, Potepanja po poteh Šavrinke Marije, Ljubljana 2000.; Marija Knez, Taku je blo anbot: KD Šavrini in anka Šavrinke, Gračišče 2011.

6 Jernej MLekuž, „Izbrani vidiki zaposlovanja beneških deklet v gospodinjstvih italijanskih mest: tiha grenko-sladka, nikoli povsem izrečena in slišana zgodba“, Dve domovini: razprave o izseljenstvu, 19/2004., 141-164; IsTI, „Življenjska pripoved migrantke Luise: prispevek za 'drugačno’ družbeno geografijo“, Geografski vestnik, 76/2001., br. 1, 37-52.

7 Marjan DrnovšEK, „Amerika: raj za ženske“, Zgodovina za vse, 4/1997., br. 1, 20-30; Irena Gantar Godina, „Slovenske izobraženke v Pragi“", Dve domovini: razprave o izseljenstvu, 16/2002., 186-189.

8 Mateja Raten, „Slovenske hišne pomočnice v Beogradu pod okriljem Katoliške cerkve in (razpuščene) Slovenske ljudske stranke v tridesetih letih 20. stoletja“, Zgodovinski časopis, 68/2014., br. 3-4, 372-387.

9 Pisala je o tome npr. Barbara Riman, „Slovenske dekle na radu u Hrvatskoj krajem 19. i početkom 20. stoljeća“, u: Uzduž i poprijeko. Brak, zakon i gradanstvo u povijesnoj i suvremenoj perspektivi (ur. Anita Dremel i dr.), Zagreb 2015. 125-134. 
dobi, da na njihovo obavljanje te službe nije bilo nikakvih prigovora, i da su se naše bake (...), rado i zapravo s ljubavlju sjećale svojih Nanika i svojih Francika. I još jedno: slovenska su dekleta svojim službovanjem u našoj zemlji - koje se ponekad, nažalost, završavalo pretužnom starošću - zaslužila da im i hrvatska sociologija posveti jedan ozbiljan rad. ${ }^{10}$

Upravo ovaj citat ukazuje na potrebu da se pokuša odgovoriti na pitanja koja se otvaraju prilikom razmišljanja o Slovenkama u Hrvatskoj. Nažalost, o njima se nije puno pisalo, a budući da je vremenski odmak relativno velik, više ne postoje izravni svjedoci o tome što su te žene prolazile. One su dio povijesti svakodnevice o kojem se često nije pisalo, niti govorilo i stoga je potrebno podatke dobiti iz drugih izvora.

Rad se temelji na podacima dobivenima iz novina, koje kao sekundarni povijesni izvor mogu pružiti sliku socijalnih i ekonomskih prilika određenog kraja u određenom vremenu. Neiscrpno su vrelo podataka za ovdje promatranu tematiku jer je iz njih moguće iščitati onodobnu opservaciju o raznim problemima i događajima koji su zaokupljali javnost. ${ }^{11}$

\section{Slovenke u Hrvatskoj}

Razlozi doseljavanja stanovništva s prostora Slovenije u Hrvatsku različiti su, a u razdoblju od kraja 19. stoljeća pa do 60-ih godina 20. stoljeća jedan je od glavnih razloga uglavnom bio posao. ${ }^{12}$

Promatrajući strukturu doseljenog slovenskog stanovništva, važno je napomenuti da je spolna nejednakost jedna od karakteristika koja je obilježila cijelo 20. stoljeće. Prema popisu stanovništva iz 1910. godine, zabilježeno je 7.320 Slovenaca i 8.366 Slovenki. ${ }^{13}$

Na prostoru cijele Banske Hrvatske je 1910. godine od ukupne slovenske populacije bilo 54\% žena, ali na području Zagreba bilo je čak 60\% ženskog slovenskog stanovništva. Žene su u Zagrebu, ali i u drugim većim industrijskim centrima Hrvatske tražile prije svega zaposlenje i plaću. ${ }^{14}$

Za razdoblje između dvaju svjetskih ratova za prostor Hrvatske nemamo podataka o spolnoj i starosnoj strukturi slovenskog stanovništva. No, već 1948. godine u Hrvatskoj su, prema popisima stanovništva, zabilježena 38.734 Slovenaca, a od toga je bilo 57\% žena. Trend u kojem prevladava ženska populacija slovenskog stanovništva u Hrvatskoj nastavila se tijekom cijele druge polovine 20. stoljeća. ${ }^{15}$ Prema popisu iz 2011. godine, ta je diskrepancija još i veća te je zabilježeno 3.346 Slovenaca i 7.171 Slovenka. ${ }^{16}$

\footnotetext{
10 Filip ŠKILJAN, „Pisanja slovenskoga časopisa Odmev 1932. i 1933.“, Studia lexicographica: časopis za leksikografiju i enciklopedistiku, 4/2010., br. 1 (6), 150.

11 Mirjana Jurić, „Zagreb u Prvom svjetskom ratu: povijesne novine kao izvor za istraživanje socijalne povijesti“, $L i$ bellarium: časopis za povijest pisane riječi, knjige i baštinskih ustanova, 2/2009., br. 2, 122.

12 Vera KRŽIŠNıK-BukIĆ, „Okvirni pregled poteka, vzrokov in pomena izseljevanja Slovencev na Hrvaškoj“, Razprave in gradivo: revija za narodnostna vprašanja, 29-30/1994. - 1995., 87.

13 Agneza Szabo, Socijalna struktura Slovenaca u Kraljevini Hrvatskoj i Slavoniji između 1880. i 1910. godine“, u: Slovenci v Hrvaški (ur. Vera Kržišnik-Bukić), Zagreb 1995., 90.

14 Isto, 85.

15 Katarina PAJNič, „Ekonomski položaj in demografska struktura Slovencev na Hrvaškem: včeraj, danes, jutri“, Razprave in gradivo: revija za narodnostna vprašanja, 80/2018., 70.

16 Državni zavod za statistiku, Popis stanovništva 2011. (https://www.dzs.hr/)
} 


\section{Slovenke u Zagrebu}

Doseljavanje žena iz Slovenije, koje su bile u potrazi za poslom, u Zagreb trebalo bi imati posebno mjesto u slovenskoj povijesti. Mlade djevojke i žene odlazile su iz istog razloga i u druge krajeve Hrvatske. Djevojke iz slovenskih krajeva tražile su zaposlenje i u Osijeku, Slavonskom Brodu, na Sušaku i u Splitu te vjerojatno i u drugim gradovima u kojima su vidjele mogućnost zaposlenja.

Svakako je Zagreb u tom doseljavanju imao važnije mjesto od drugih, manjih hrvatskih gradova. Nakon Prvoga svjetskog rata postaje jedan od središnjih gradova Kraljevine Srba, Hrvata i Slovenaca. Iako nije političko središte, dvadesetih godina 20. stoljeća predstavlja vrlo jako industrijsko, trgovačko i bankarsko središte nove države. To ujedno dovodi i do gospodarskog i demografskog razvitka te urbanizacije. Broj se stanovnika grada Zagreba povećava pa tako 1910. godine ima 79.038 stanovnika, 1921. godine 108.674 , a 1931. godine 185.582 stanovnika. ${ }^{17}$ Demografski rast nije posljedica nataliteta, već je na to utjecalo i doseljavanje stanovništva. Nakon rata doseljava se velik broj stanovnika iz različitih dijelova Hrvatske i Slavonije, Istre, Dalmacije te Slovenije i Bosne. Dvadesetih godina u Zagrebu bile su povoljne gospodarske prilike pa je mnogo ljudi tražilo u gradu posao i priliku za bolji život. Upravo u to vrijeme i velik broj, ponajviše djevojaka i žena, dolazi u Zagreb kako bi služile i živjele u građanskim obiteljima kao kućne pomoćnice.

Mnogo djevojaka i žena bilo je iz različitih slovenskih krajeva. Prema podacima dobivenima iz Župe Gornji grad, u Zagrebu je u razdoblju od 1918. do 1928. godine od ukupno 89 umrlih služavki 13 bilo s prostora Slovenije, i to iz Celjâ, Ptuja, Brežicâ i Krškog. Statistički gledano, to bi bilo nešto više od $11 \%^{18}$, no ovo čini samo ilustrativan prikaz. Svakako bi analiza drugih matičnih knjiga u Zagrebu dala vrlo zanimljive podatke o djevojkama i ženama koje su radile kao kućne pomoćnice. Potrebno je napomenuti da mnoge od njih nisu bile prijavljene, odnosno sve do sredine 30-ih godina 20. stoljeća nije postojala zakonska regulativa koja bi štitila njihov ionako ranjiv položaj.

Zbog nedostatka pravne zaštite, kućne su pomoćnice često bile metom iskorištavanja vlastitoga gospodara. Radno vrijeme najčešće je trajalo cijeli dan. Navedeni radni uvjeti bili su teški i za mlade djevojke, a ostarjele bi služavke, kad više ne bi mogle funkcionirati u takvim uvjetima, najčešće završile na ulici, uz minimalnu ušteđevinu, ili bi se vraćale u rodni kraj kako bi živjele sa svojom obitelji. ${ }^{19}$

Upravo zato bitnu ulogu imaju društva koja su okupljala djevojke i žene koje su radile u Zagrebu. Socijalna skupina kućnih pomoćnica bila je vrlo osjetljiva zbog dobi, spola, obiteljskog statusa i egzistencije. Naime, zbog nestalnosti posla koji je ovisio o preporuci poslodavca u služinskoj knjižici, slabe plaće, nedostatka socijalne zaštite i skrbi, brojna onodobna humanitarna društtva bila su usmjerena na zaštitu kućnih pomoćnica. Najčešće su to bile siromašne djevojke iz ruralnih sredina bez ikoga u gradu pa im je o pronalasku posla ovisila i egzistencija jer je kućna služinčad stanovala kod poslodavca. Problem

\footnotetext{
17 Mira Kolar-Dimitrijević, Radni slojevi Zagreba od 1918. do 1931., Zagreb 1973., 18.

18 Dunja Jakopović, Kućna služinčad u gradu Zagrebu dvadesetih godina 20. stoljeća, diplomski rad, Zagreb $2018 ., 28$.

19 Isto, 32.
} 
je predstavljalo i nepostojanje mirovinskog osiguranja, tj. radničkog osiguranja u slučaju starosti i iznemoglosti koje, iako je bilo predviđeno za služinčad, nije postojalo. Zato je djelovanje brojnih humanitarnih društava bilo usmjereno na zaštitu djevojaka i žena koje su dolazile u grad u potrazi za poslom, a svrha im je bila u prvom redu osigurati egzistenciju i, u krajnjoj liniji, zaštitu od sve većeg problema svodništva i trgovine bijelim robljem. Neka su društva u svojim odrednicama imale zadatak okupljati djevojke na temelju pripadnosti te su se tako u Zagrebu osnivala i slovenska djevojačka društva.

Iako su zabilježeni i raniji pokušaji osnivanja slovenskog ženskog društva, prvo društvo koje je bilo registrirano u Zagrebu bila je Marijina družba, koja je s radom započela 1925. godine. U okviru njega okupljale su se, međusobno se podupirale i nudile pomoć. Osnovni cilj bila je međusobna pomoć članicama i briga za zajedničko druženje u slobodno vrijeme. $S$ djelovanjem je Društvo počelo organiziranjem zajedničkih duhovnih vježbi, i to već prije samog formalnog osnivanja. Aktivnosti su postale složenije: organizirale su se priredbe, predavanja i kulturno-društvene večeri. Kao što je već spomenuto, važnu ulogu imali su svećenici, odnosno dušobrižnici: o. Gabrijel Cevc, Anton Prešeren, Janez Kozelj, Rudolf Pate i drugi. ${ }^{20}$ Društvo nije prestalo djelovati, već se preimenovalo u Dekliško društvo „Ognjišče“ 1935. godine. Aktivnosti su bile slične onima koje su se izvodile u društvu Marijina družba. Prema informacijama, Društvo je djelovalo do početka Drugog svjetskog rata, a u razdoblju od 1935. do 1939. godine uspjelo je pomoći oko 4.000 žena. ${ }^{21}$

Usko povezano s Marijinom družbom bilo je društvo Dekliško zavetišče „Naš dom Zagreb“, osnovano 1932. godine kako bi se osigurao dom ženama i djevojkama koje bi se u vrijeme traženja posla zatekle bez smještaja. ${ }^{22} \mathrm{Na}$ početku 1930 -ih počela se prikupljati pomoć za osnivanje spomenutog Društva, a pomoć za izgradnju doma tražila se i u Sloveniji, prije svega od Marijinih družbi koje su djelovale u različitim slovenskim župama. ${ }^{23} \mathrm{~S}$ djelovanjem je Društvo prestalo 1935. godine.

Djevojačka društva imala su važnu ulogu te su često u novinskim tekstovima, kada su izvještavala o radu, napominjala i savjetovala djevojkama da se učlane radi sigurnosti. Svakako je tu bilo i potreba za financijskom podrškom društvu koje je ono dobivalo većim brojem članova.

\section{TeKstovi u SLOVEnSKim nOVINAMA}

Iz svega prije rečenoga potrebno je još jednom naglasiti da je ova tema relativno neistražena. Nije problem samo u njezinoj eventualnoj nezanimljivosti, već je vjerojatno i sâm

20 Bogdan Kolar, „Delo slovenskih duhovnikov med Slovenci v Zagrebu med obema vojnama“, u: Slovenci v Hrvaški, $115-131$.

21 „Ognjišče dekliško zavetišče v Zagrebu“, Slovenec (Ljubljana), br. 64a, 17. 3. 1940., 5; „Slovenska Marijina družba v Zagrebu ob 15 letnici“, Slovenec (Zagreb), br. 97, 28. 4. 1940., 7; „Izven meja Slovenije“, Slovenski gospodar (Maribor), br. 21, 22. 5. 1940., 2 .

22 B. Riman, „Slovenska društva u Hrvatskoj između dva svjetska rata“, Časopis za suvremenu povijest, 46/2014., br. 1, 118-119.

23 B. Kolar, „Delo slovenskih duhovnikov“, 128. 
pristup istraživanju života i rada kućnih pomoćnica na određen način podosta nezahvalan. Naime, velik dio tih žena nije bio prijavljen, stoga se o njima u mnogim slučajevima znalo relativno malo, a ako bi se došlo do podataka, bila bi riječ o imenima i prezimenima te radnom vijeku pa bi bilo teško zaključiti kakav je bio život slovenske kućne pomoćnice u Zagrebu jer bi do drugih potankosti vjerojatno bilo teže doći. Upravo su zato novinski članci koje su objavljivale slovenske novine bogat izvor podataka, često više od samog imena i prezimena djevojaka i žena koje su se bavile ovim poslom.

Iščitavajući novinske članke u razdoblju između dvaju svjetskih ratova, stječe se dojam da je život tih djevojaka i žena doista bio težak i često ispunjen gorčinom. Svi su članci prihvaćeni s određenim oprezom zbog činjenice da su neki vjerojatno napisani i s ciljem da djevojke koje odlaze u svijet odvrate od te ideje. Ipak, prikupljene tekstove moguće je podijeliti na tri skupine.

Prva skupina jest ona koja o ženama koje odlaze u svijet za poslom (prije svega se ovdje spominje Kraljevina Jugoslavija). Piše se upozoravajuće, savjetuju ih ili pozivaju da ostanu kod kuće jer „... nije sreća boraviti u gradovima, već obrađivati svoja polja, živjeti na svojoj zemlji i među svojim ljudima." ${ }^{24} \mathrm{U}$ tu se skupinu mogu svrstati i tekstovi koji na određen način brane položaj i posao djevojaka i žena pred omalovažavanjem tog zanimanja. Ujedno su i često upozoravali na probleme koji se javljaju te kako državne institucije koje su upoznate $s$ razmjerima tih problema ne čine dovoljno. Problem je bila i sama politika, koja nije donijela prikladne zakone kako bi se položaj tih djevojaka poboljšao.

Druga skupina tekstova govori o tragičnim sudbinama djevojaka ili žena iz Slovenije koje su ih zahvatile na radu u Hrvatskoj. Prilikom pregleda novina bilo je puno izvještaja o tragičnim sudbinama, ali smo ovdje izdvojili samo one u kojima je bilo jasno napisano da je djevojka ili žena bila iz Slovenije ili da je Slovenka. Da su se objavljivale i pozitivne vijesti u novinama, vjerojatno (ili barem želimo vjerovati) bi bilo i takvih tekstova u kojima je zapisano da su si te iscrpljene i islužene žene na kraju ipak uspjele osigurati dostojnu starost.

Kao treću skupinu tekstova možemo promatrati izvještaje i na neki način reklame djelovanja različitih djevojačkih društava. U tim tekstovima upućuje se često djevojke da se priključe nekom djevojačkom društvu. Tako je bilo moguće iščitati slične pozive kao što je ovaj: „Draga slovenska djevojčadi u Zagrebu! Dođite među nas, u našu sredinu, gdje ćemo Vas primiti kao sestre, gdje ćemo moćno osjetiti toplinu domaćeg ognjišta, miris domaće zemlje“25. Ovdje se neće iznijeti poseban naglasak na te vrste tekstova jer su to zapravo obavijesti o djelovanju tih društava, o kojima je već bilo riječi. ${ }^{26}$

Tekstove koje je moguće uvrstiti u prvu skupinu nalazimo od početka 20-ih godina 20. stoljeća pa sve do početka Drugog svjetskog rata. Obično izlaze veći novinski članci u kojima se ujedno često iznose i statistički (objektivni) podaci vezani za primjere iselja-

24 „...ni sreča tlačaniti v mestih, ampak obdelovati svoj polja, živeti na svoji zemlji in med svojimi ljudmi“ („Žalostna usoda slovenskih deklet“, Mariborski večernik „Jutra“(Maribor), br. 93, 24. 4. 1929., 2)

25 „Draga slovenska dekleta v Zagrebu! Pridite med nas, v našo sredo, kjer Vas bomo sprejele kot sestre, kjer bomo močno čutile toploto domačega ognjišča, dih domače zemlje!“ („Slovenska dekleta v Zagrebu“, Vigrede, 17/1939., br. 10, 394)

26 B. Riman, „Slovenska društva u Hrvatskoj“. 
vanja, odnosno rada u određenim krajevima. Slične tekstove koje nalazimo za prostor Zagreba moguće je u slovenskim novinama pronaći i za druge gradove (Beograd, Sarajevo itd.).

Odlazak mladih djevojaka bio je jedan od temeljnih problema slovenskoga društva krajem 19. i početkom 20. stoljeća koji se često spominje i u onodobnim tiskovinama, gdje se naglašava kako djevojke na rad odlaze bez socijalne skrbi i nisu osigurane ako se razbole ili u slučaju starosti, a često se mogu naći i oglasi u kojima se traže Slovenke.

Iako je taj problem bio prepoznat već 20 -ih godina 20. stoljeća - a prepoznala ga je slovenska Crkva - sve do 30-ih godina nisu bili napravljeni nikakvi ozbiljniji koraci kako bi se tim djevojkama i ženama pomoglo. Kao i u istraživanju u suvremeno doba, tako je i prije pozornost prije svega bila usmjerena na žene koje su odlazile, kako se pisalo, u „tuđinu“ te je unutarnja dijaspora bila manje uočljiva, ali nailazilo se na mnoge probleme. U samom se početku njihovi odlasci promatraju usputno pa je tako Janez Kalan, kada je obilazio slovenske zajednice u Hrvatskoj i Srbiji još 1922. godine, napisao da u Varaždinu ima mnogo djevojaka, „Štajerk“" ${ }^{27}$ koje rade kao kućne pomoćnice. O njima se pisalo i ovo:

Također i po drugim hrvatskim i srpskim mjestima, gdje je kakva Slovenka, neka se udruže i organiziraju! Iz Virovitice traže Bogoljuba, iz Vinkovaca izvještavaju da je ondje „kraj kršćanskog života“, da sluškinje ne smiju u crkvu itd. U Brodu ih je nekolicina i Bog zna gdje su sve. Neka napiše iz svih tih krajeva barem po jedna i kaže koliko ih je te malo opiše tamošnje razmjere. Onda ćemo vidjeti što možemo učiniti. ${ }^{28}$

Nekako se problem počeo ozbiljnije osvješćivati 30-ih godina 20. stoljeća. O tome pišu uglavnom pojedinci koji su se susretali s tim ženama i djevojkama te shvatili raširenost tog problema. Tako je u Mariborskem večerniku „Jutra“ izašao tekst pod naslovom „Žalostna usoda slovenskih deklet“, gdje, između ostaloga, piše sljedeće:

Jedno je od najžalosnijih poglavlja slovenskog naroda uvijek bilo pitanje njegovih djevojaka, koje su zbog socijalne bijede bile prisiljene tražiti zaradu u velikim stranim mjestima. Trst, Graz, Beč Aleksandrija itd., to su prije oslobađanja bila grla koja su, iz godine u godinu, progutala tisuće i tisuće kćeri naših poljoprivrednika i radnika. Mlade, zdrave i pune života napuštale su dom, a vraćale se tjelesno iscrpljene, često bolesne te moralno pokvarene. No, one koje su se vratile kući barem su bile sretne jer ih je velik dio ostao u tuđini. Jedne su (...) podlegle bolestima, druge su prestale biti dobre te su išle na ulicu, a treće, kojih je bilo najmanje, jedva su našle bolje, ali stalno rješenje u braku. Čak i posljednje, najsretnije među svima, obično su izgubljene za naš narod. (...) Umjesto u Trst, Graz, Beč i Aleksandriju, naše djevojke okrenule su se Zagrebu, Beogradu, Sarajevu, Skoplju itd. Danas su kćeri naših sela i radnih kolonija rastresene kao sluškinje, sobarice, konobarice itd. po cijeloj Jugoslaviji. Mogli bismo reći da u našoj državi nije većeg mjesta gdje ne bi bilo slovenskih djevojaka. Samo ih je u Zagrebu i u Beogradu na tisuće, a u ostalim mjestima nije ih puno manje. Na tisuće i tisuće slovenskih sluškinja, sobarica, konobarica uzeli su nam ti naši istočni i južni

27 Janez Kalan, „Slovenci med Hrvati in katoličani v Belgradu“, Bogoljub, 20/1922., br. 12, 271.

28 „Tudi po drugih hrvaških in srbskih mestih, kjer je kaj Slovenk, naj se združijo in organizirajo! Iz Virovitice pišejo po Bogoljuba, iz Vinkovce pa poročajo, da je tam 'konec krščanskega življenja', da služkinje ne smejo v cerkev itd. V Brodu jih je nekaj, in Bog ve, kje še vse. Naj piše iz vseh teh krajev vsaj po ena in pove, koliko lih je ter malo opiše ondotne razmere. Potem bomo videli, kaj se da storiti.“ („Po domovini“, Bogoljub (Ljubljana), br. 4, 20/1922., 90-91). 
krajevi. Sve te djevojke prepuštene su gotovo same sebi, za njih se nitko ne brine ni ondje ni ovdje kod kuće, i na njih mislimo samo onda kada čitamo u časopisima zaključak ove ili one tragedije, a prepoznamo po imenu i mjestu rođenja da je bila Slovenka (...). ${ }^{29}$

Slične tekstove možemo naći i u kasnijem razdoblju. Tako je u Ljudskoj pravici 1934. godine napisano: „Bez zaštite socijalnog zakonodavstva nisu osigurane u slučaju bolesti ili starosne nemoći. I odmor i sloboda ovise samo o dobroj volji gospodara." ${ }^{\text {"30 }}$

Koliko je problem djevojaka koje su odlazile iz Slovenije bio velik govori i činjenica da je 1934. godine tiskan priručnik pod nazivom „Če greš na tuje“ u kojem im se, između ostaloga, savjetuje da ostanu u Sloveniji, ali i ako se odluče na odlazak, donose se mnogi savjeti, kao i popis društava i samostana u kojima djeluju slovenski svećenici kojima bi se mogle obratiti za savjet i pomoć.

Slovenske djevojke, ostanite kući! Ako već odlazite iz kuće, ne radite sramotu svojima u domovini, svojem narodu! Ako moraš otići od doma, u tuđinu, odi tako da si time već osiguraš sreću u tuđini. ${ }^{31}$

Te se djevojke obično okarakteriziralo i javno prozivalo kao djevojke i žene slabijeg morala te se često tvrdilo da su Slovenke na slabijem glasu nego Hrvatice i Srpkinje koje rade iste poslove. Upravo su zato duhovni vođe upozoravali na potrebu da djevojka, i ako ode iz svojeg kraja, bude i dalje vezana za Crkvu. Potonja je, pak, posebnu opasnost vidjela za djevojke koje su odlazile raditi u Srbiju zbog pravoslavlja i nemogućnosti redovitog odlaska na misu.

Nerijetko se u različitim novinama mogu vidjeti upozorenja, koja su ponekad i nevezana za temu u o kojoj se piše u članku. Jedno je od takvih i ovo:

U velikom su mjestu mlade djevojke prepuštene same sebi, izložene su velikoj opasnosti, posebno ako nemaju zaposlenje. Zato mnoga žalosno zađe i padne, te je i sebi i drugima problem, svim Slovencima na sramotu. ${ }^{32}$

29 „Eno najbolj žalostnih poglavij slovenskega naroda je bilo vedno vprašanje njegovih deklet, ki so bila vsled socijalne bede prisiljena iskati si zaslužka v velikih tujih mestih. Trst, Gradec, Dunaj, Aleksandrija itd., to so bila pred osvobojenjem žrela, ki so leto za letom požirala tisoče in tisoče hčera naših kmetov in delavcev. Mlade, zdrave in polne življenja so odhajale z doma, nazaj so se pa vračale telesno izžete, čestokrat bolne in tudi moralno pokvarjene. Toda tiste, ki so se vrnile domov, so bile vsaj srečne, kajti velik del jih je ostal v tujini. Ene so (...) podlegle boleznim, druge so se izpridile in so šle na ulico, tretje, in teh je bilo najmanj, so komaj našle boljšo ali stalno rešitev v zakonu. Pa tudi te poslednje, najsrečnejše med vsemi, so bile navadno izgubljene za naš narod. (...). Namesto v Trst, Gradec, Dunaj, Aleksandrijo itd. so se obrnila naša slovenska dekleta v Zagreb, Beograd, Sarajevo, Skoplje itd. Danes so hčerke naših vasi in delovskih kolonij raztresene kot služkinje, sobarice, natakarice itd. po vsej Jugoslaviji. Reči bi mogli, da ga ni v naši državi večjega kraja, kjer bi ne bilo slovenskih deklet. Samo v Zagrebu in v Beogradu jih je na tisoče, a v ostalih mestih tudi ne dosti manj. Na tisoče in tisoče slovenskih služkinj, sobaric in natakaric so nam pobrali naši vzhodni in južni kraji. Vsa ta dekleta so prepuščena skoraj samo sama sebi; za nje se nihče ne briga niti tam niti tu doma, in nanje mislimo samo takrat, kadar čitamo v časopisih zaključek tragedije te ali one, o kateri zvemo po imenu in rojstnem kraju, da je bila Slovenka.“ („Žalostna usoda slovenskih deklet“, Mariborski večernik „Jutra“ (Maribor), br. 93, 24. 4. 1929., 2)

30 „Brez zaščite socialne zakonodaje niso preskrbljene ne za slučaj bolezni, ne starostne onemoglosti. Tudi njih počitek in prostost zavisita le od dobre volje gospodarja.“ („Naša dekleta“, Ljudska pravica (Lendava), br. 6, 14. 12. 1934., 2)

31 „Slovenska dekleta, ostanite doma! Če greste pa z doma, ne delajte sramote svoji domovini, svojemu narodu! Če pa moraš oditi z doma, na tuje, odidi tako, da si že s tem zagotoviš srečo v tujini." (Franc Grivec, Alojz Odar i Kazimir ZaKrajšEK, Če greš na tuje, Ljubljana 1934., 15)

32 „V velikem mestu pa so mlada dekleta prepuščena samim sebi, izpostaviljena velikim nevarnostim, posebno, če nimajo službe. Zato marsikatera žalostno zaide in pade, da je sebi in drugim v nadlego, vsem Slovencem pa v sramoto.“ („Slovenci v Zagreb! Rojaki! Slovenci!“, Domoljub (Ljubljana), br. 45, 11. 11. 1921., 3) 
Vjerojatno je jedan dio djevojaka na kraju i pokleknuo te se iz novinskih tekstova, koje smo uvrstili u drugu skupinu, vidi kako su znale biti uhićene i optužene da su prijateljice noći. Često se znalo dogoditi i da su svoj život završile zbog teških životnih uvjeta i nezakonitog djeteta za kojega su se borile. Prema onome što se opisuje u novinama, kada se piše o uvjetima i načinu života, može se zaključiti da su mnoge od njih imale vrlo teške životne uvjete radeći kao kućne pomoćnice. Svakako je potrebno spomenuti i da nisu imale obiteljsku podršku te da su u trenucima kada nisu imale zaposlenje ili su oboljele bile prepuštene same sebi. Mnoge su od njih zarađeni novac slale kući, u Sloveniju. Naravno da nije sva krivnja uvijek bila na poslodavcima, već je splet nesretnih okolnosti utjecao na daljnji život tih djevojaka. Mnoge zbog vrste posla nisu imale mogućnost osnivanja vlastite obitelji te su svoju starost, kao što upozoravaju kroničari onodobnog života, dočekale na teret obitelji (daljnjih članova) koju su u mladosti napustile. Ako se razmotre podaci iz novina Slovenski dom, onda je vidljivo da je život tih sluškinja bio težak. Zabilježeno je sljedeće:

Pogotovo se brojno zastupalo slovenske sluškinje koje dosežu čak 40 posto od ukupnog broja svih zagrebačkih sluškinja. To je dokaz da slovenske sluškinje u zagrebačkim obiteljima imaju posebnu čast. Baš ništa čudno ne predstavlja ta činjenica; opće je poznato da su naše sluškinje izrazito odgovorne, točne, brižne i snažne. (...) Zato je i razumljiv velik broj upita za slovenske sluškinje koje su u Zagrebu vrlo cijenjena i poštovana radna sila u kući. (...) Prema statistikama, prosječna je mjesečna plaća sluškinje okruglih 270 dinara. Taj iznos vrijedi samo za one sluškinje koje su prijavljene. Djevojčice, koje su mlađe od 14 godina, a također su zaposlene u domaćinstvu, za svoj rad često dobiju mjesečno samo 50 dinara. U Zagrebu je ukupno zaposleno oko 10.000 sluškinja, a od toga Slovenki 40\%, dok su 52\% Hrvatice (...) Po godinama je najviše takvih koje su zaposlene i imaju između 20 i 25 godina, a manje je onih između 30 i 40 godina. Nakon te starosne granice broj sluškinja naglo opada. Među njima je $92 \%$ nevjenčanih, $6 \%$ vjenčanih, a ostale žive u zajedničkom kućanstvu. (...) Statistika pokazuje da su slovenske sluškinje s visokim postotkom gotovo sve pismene. Zapošljavaju se većinom djevojke koje kući nemaju nikakvog imetka (...). Bez ikakvog je imetka 92\% svih sluškinja. Radni dan iznosi u $40 \%$ sluškinja po 16 sati, a u $48 \%$ i po 18 sati dnevno. ${ }^{33}$

Iako je iznesen problem s kojima se sluškinje u Zagrebu, ali i u drugim gradovima svakodnevno susreću, zaključak je članka bio sljedeći: „Slovenske sluškinje, koje su u vrlo poštovanim zagrebačkim obiteljima, u svakom su pogledu na mjestu. Od svih su najobrazovanije, zanimaju se za javni i kulturni život.“34 Upravo je ta tvrdnja jedan od razloga zbog kojeg se često u novinskim oglasima tražilo upravo „slovensko dekle“.

33 „Zlasti številno pa so zastopane slovenske služkinje, ki dosegajo kar 40 odstotkov od skupnega števila vseh zagrebških služkinj. To je dokaz, da slovenske služkinje pri zagrebških družinah prav posebno v časteh. Prav nič čudnega ne predstavlja to dejstvo, saj je splošno znano, da so naše služkinje v službi izredno vestne, natančne, skrbne in snažne. (...) Zato je tudi razumljivo veliko povpraševanje po slovenskih služkinjah, ki so v Zagrebu zelo cenjena in upoštevana delovna moč v hiši. (...) Po statistiki je povprečna mesečna plača služkinje okroglo 270 dinarjev. Velja pa ta vsota le za tiste služkinje, ki so prijavljene. Deklice, ki so stare manj kakor 14 let, pa so tudi zaposlene v gospodinjstvu, pa dobe mesečno za svoje delo pogosto le po 50 din. V Zagrebu je zaposlenih vsega skupaj približno 10.000 služkinj, od teh je Slovenk 40\%, 52\% pa je Hrvatic. (...) Po starosti jih je največ takih, ki so v službi med 20 in 25 leti, manj pa jih je med 30 in 40 leti. Nad to starostno mejo število služkinj naglo pada. $92 \%$ je med njimi neporočenih, $6 \%$ jih je poročenih, ostale pa žive v skupnem gospodinjstvu. (...) Statistika kaže, da so slovenske služkinje z visokim odstotkom domala skoraj vse pismene. V službo hodijo večinoma dekleta, ki doma nimajo nikakršnega premoženja. (...), je brez slehernega premoženja $92 \%$ vseh služkinj. (...) Delovni čas znaša pri 40\% služkinj dnevno do 16 ur, pri 48\% pa tudi po 18 ur dnevno.“ („Slovenske služkinje v Zagrebu“, Slovenski dom (Ljubljana), br. 20, 25. 1. 1939., 3)

34 „Slovenske služkinje, ki so pri zagrebških družinah zelo v časteh, so res tudi v vsakem pogledu na mestu. Od vseh so tudi najbolj izobražene, se tudi najbolj zanimajo za javno ter kulturno življenje." (Isto) 
O problemu velikog broja slovenskih sluškinja, kao i o njihovu teškom životu izvještavao je i časopis zagrebačkih Slovenaca, Odmev, a sve u svrhu da senzibilizira i slovensku zajednicu u Zagrebu. U Odmevu je izašao poduži članak upravo o temi Slovenki i njihova rada u Zagrebu. ${ }^{35}$

Vidljivo je da su slovenski mediji bili svjesni problema slovenskih djevojaka i žena, njihova rada u različitim krajevima Kraljevine Jugoslavije izvan Slovenije te da su pokušavali i širu javnost informirati o problemima s kojima su se one susretale. Čini se da su novinari/urednici novina često bili svjesniji problemâ od političarâ, koji su određenim zakonima trebali regulirati pružanje pomoći kućnoj posluzi, na što se upozoravalo u člancima. ${ }^{36}$

Iz iznesenog vidljiv je opis teškog položaja u kojemu su se često nalazile žene i djevojke koje su odlučile otići raditi u neki grad Kraljevine Jugoslavije. Upravo zato ne začuđuje da su se, osim prije navedenih vrsta tekstova, u slovenskim novinama nerijetko navodili i tragični slučajevi kada su si djevojke oduzele život ili počinile kakvo drugo nedjelo.

Slovenske su novine najčešće izvještavale o samoubojstvima ili pokušajima samoubojstava djevojaka. Osim samog tog čina, u tim tekstovima mogla se vidjeti i dob, kao i mjesto iz kojega su djevojke i žene dolazile u Zagreb. Razlozi samoubojstva ili njegova pokušaja bili su različiti, ali su najčešće djevojke to činile zbog neuzvraćene ljubavi ili financijske oskudice u kojoj su se našle. Zapravo neki od tih događaja otkrivaju sav jad i težinu života tih djevojaka i žena.

Načini na koji su si djevojke često oduzele život bili su jezivi i bolni. Razlozi su bili različiti, a za neke se nije ni doznalo zašto su odlučile skončati.

Tako se može iščitati da je M. D. ${ }^{37}$ iz Podsela kod Celjâ okončala život skočivši s mosta u Savu. Pokušala je počiniti samoubojstvo i ranije. U novinama se navodi da je mjesec dana prije nego što je skočila s mosta legla na željezničku prugu, ali da ju je u zadnji trenutak spasio jedan mladić. Tada je na saslušanju rekla kako ne može dobiti posao te je policiji izjavila da je gladna, gola i bosa i da joj nije jasno što još radi na tom svijetu. Očigledno nije mogla pokriti niti najosnovnije životne potrebe te je, nažalost, drugi put uspjela u svojem naumu. ${ }^{38}$

T. H. je život okončala skočivši pod vlak. Imala je 23 godine, a bila je iz Sv. Petra pod Sv. Gorama kod Brežica. ${ }^{39}$

Isto je učinila i T. H., koja je imala 20 godina. Razlog je bio taj što nije uspjela pronaći posao. Tužno je u ovoj priči to što su upravo tu djevojku mjesec dana ranije pokušali odgovoriti od samoubojstva. Naime, budući da se čudno ponašala, željezničar je pozvao policiju koja je, nakon što je shvatila problem, predala djevojku Zavodu za nezaposlene, gdje su joj obećali pomoći u pronalaženju posla. Nažalost, izgleda da ipak nije uspjela u svojem naumu te da nije vidjela drugog izlaza iz problema u kojima se našla. ${ }^{40}$

\footnotetext{
35 Filip ŠKiljan, „Pisanja slovenskoga časopisa Odmev“, 119.

36 „Dobrodelna društva in problem služkinj“, Jutro (Ljubljana), br. 33, 14. 8. 1933., 2.

37 U novinama se donose imena i prezimena djevojaka i žena koje su počinile samoubojstvo, ali u ovom će se članku iznijeti samo inicijali zbog relativne osjetljivosti tematike o kojoj se piše.

38 „Tragedija slovenske služkinje v Zagrebu“, Slovenski narod (Ljubljana), br. 29, 28. 2. 1935., 2.

39 "Slovenko povozil vlak“, Jutro (Ljubljana), br. 233, 9. 10. 1926., 3.

40 „Ena med 30.000“, Slovenec (Ljubljana), br. 88, 18. 4. 1929., 3.
} 
J. U., 43-godišnjakinja, ubila se zbog neimaštine. Ovo je posebno tragična priča. Rodom iz Vidma kod Brežica, dugo je godina služila u Zagrebu kao kuharica. Svoju je ušteđevinu posudila poznanici, a kada je ostala bez zaposlenja, tražila je povrat novca kako bi mogla normalno živjeti. No, njezina poznanica nije priznavala dug i nije joj vratila novac. Ne vidjevši drugog izlaza, J. U. bacila se pod vlak. ${ }^{41}$

Tužna je i sudbina H. T. iz Črne kod mjesta Prevalje, koja je radila kao konobarica u Zagrebu. Nakon smrti svojega muža, živjela je sa sinom. Otrovala se jer se nije mogla brinuti za sebe i sina, kojega je također pokušala otrovati, ali su ga uspjeli spasiti. ${ }^{42}$

M. Š. iz naselja Štore kod Celjâ skočila je u rijeku Savu i utopila se jer se otac njezina nezakonitog djeteta nije želio oženiti s njom. Gubitkom službe nije mogla uzdržavati sebe i svoje dijete te si je odlučila okončati život. ${ }^{43}$

Samoubojstvo zbog nesretne ljubavi, što nije jedini primjer, počinila je M. H., koja se otrovala amonijakom jer ju je napustio zaručnik. ${ }^{44} \mathrm{~A}$. K. prerezala si je vrat zbog neuzvraćene ljubavi. ${ }^{45}$ Izgleda da se iz istog razloga otrovala i A. F., koja je imala 20 godina, i to plinom. ${ }^{46}$

Za neke djevojke nije jasno zašto su okončale svoj život. F. J., koja je imala 17 godina, otrovala se. U novinama je bilo zapisano samo to da je iz Slovenije, a razlog se ne navodi. ${ }^{47}$ Brojne su bile zapisane nesretne sudbine, gdje žene i djevojke nisu vidjele izlaza iz svojih različitih nezavidnih situacija. ${ }^{48}$

\section{ZAKLJUČAK}

Iako se o Slovenkama koje su odlazile iz svoje domovine u tuđe krajeve kako bi zaradile za svoj život i o životima onih koji su im bili najbliži malo pisalo, pomnim se istraživanjima može doći do mnogih podataka o njima. Izvori se mogu pronaći ponajviše u dnevnim časopisima. Jasno, radi se o kratkim obavijestima o zapošljavanju, pozivima na rad u određenu sredinu, ali i o njihovim poteškoćama s kojima se susreću tijekom traženja zaposlenja. Vidljivo je da su se najvećim dijelom Slovenke zapošljavale kao kućne pomoćnice i u tom poslu bile posebno cijenjene. To se vidi i iz pojedinih obavijesti u časopisima, gdje se posebno traže Slovenke za rad u kućanstvima. Premda je većina njih uspjela pronaći mir i suživot

\footnotetext{
"Samomor slovenske služkinje“, Domovina (Ljubljana), br. 1, 5. 1. $1933 ., 7$.

„Žaloigra slovenske služkinje“, Domovina (Ljubljana), br. 4, 26. 1. 1933., 6.

„Samomor slovenske služkinje v Zagrebu“, Slovenec (Ljubljana), br. 66, 21. 3. 1926., 4.

„Iz domače kronike“, Slovenski narod (Ljubljana), br. 109, 16. 5. 1926., 1.

„Ta nesrečna ljubezen“, Jutro (Ljubljana), br. 228, 30. 9. 1937., 4.

„Samomor slovenske služkinje“, Jutro (Ljubljana), br. 100, 30. 4. 1933., 6.

„Samomor slovenske služkinje“, Jutro (Ljubljana), br. 82, 10. 4. 1931., 2.

48 O samoubojstvu piše i u člancima: „Žaloigra mlade služkinje“, Domovina (Ljubljana), br. 15, 13. 4. 1933., 12; „Samomor slovenske služkinje v Zagrebu“, Slovenski narod (Ljubljana), br. 39, 24. 4. 1933., 3; „Obup slovenske služkinje v Zagrebu“, Mariborski večernik „Jutra“ (Maribor), br. 83, 12. 4. 1934., 2; „Zagoneten samomor pridne služkinje“, Mariborski večernik „Jutra“ (Maribor), br. 135, 16. 6. 1934., 2; „Obup slovenske služkinje v Zagrebu“, Slovenski narod (Ljubljana), br. 82, 27. 8. 1936., 3; „Samomor slovenske služkinje v Zagrebu, Domovina (Ljubljana), br. $22,2.7$. 1938., 6.
} 
u toj stranoj okolini, u ovom slučaju u Hrvatskoj, mnoge od njih nisu bile te sreće. Nakon odlaska iz rodnog mjesta, nepronalaženja zaposlenja i nemogućnosti povratka u rodni kraj, mnoge su okončale svoj život na najgori mogući način. O njima su se $s$ vremenom počela brinuti određena udruženja, pruživši im malenu, često samo moralnu potporu. Ipak, čini se da to nije bilo dovoljno da bi se uspjele snaći u sredinama u koje su došle.

Iz dostupnih podatka razvidno je da je velik broj djevojaka i žena iz slovenskih krajeva odlazio raditi u druge krajeve Kraljevine Jugoslavije, a Zagreb je bio jedno od važnjih središta, pogotovo u razdoblju između dvaju svjetskih ratova.

U ovom su radu prikazani samo neki od elemenata života i rada djevojaka i žena iz slovenskih krajeva koje su u Hrvatsku došle iz ekonomskih razloga. Temu je svakako potrebno dodatno istražiti, čime bi se otvorila i mnoga druga pitanja. Iako su izvori oskudni, postojeći podaci koji se mogu iščitavati u novinama, različitim časopisima, pa i u maticama pojedinih župa, ukazuju na njihov, ponekad, vrlo težak život.

\section{"Hardworkinig Slovenian maids" - A HISTORY OF THE SLOVENIAN WOMEN WORKING IN ZAGREB BETWEEN THE TWO WORLD WARS}

Summary: A large number of Slovenes has lived on Croatian territory throughout history. Census records reveal that in the $20^{\text {th }}$ century a disproportionate number of them were women. Such a strong presence of Slovenian women in Croatia was primarily motivated by economic reasons. Like their male counterparts, between the two world wars Slovenian women came to Croatia for work, primarily to industrial towns, most notably Zagreb. Research has shown that as many as 10.000 of these women found employment in Zagreb. The city was an attractive destination for several reasons. Firstly, it was relatively close to Slovenia, and secondly, it offered Slovenian women a wider variety of jobs than what was available to them at home, providing them with more opportunities to provide for themselves. The women soon gained a reputation as excellent workers.

This paper is based on two main types of sources: contemporary scholarly works, which mention the labor of Slovenian women in Croatia only sporadically, and Slovenian daily newspapers of the inter-war period, which, conversely, report on the aforementioned issue quite extensively. These reports provide a realistic portrayal of the situations these women found themselves in, often disregarded by their contemporaries. The paper also focuses on the forms of the workers' (self-)organization and delves into their difficult, often tragic lives, as those are the two aspects that stand out most in the reports. It is worth noting that this subject matter has heretofore been largely overlooked and underreported by Croatian and Slovenian historians.

Key words: the migration of women, economic migration, Zagreb, Slovenian women in Croatia, housemaids, girls' associations 


\section{Izvori}

„Dobrodelna društva in problem služkinj“, Jutro (Ljubljana), br. 33, 14. 8. 1933., 2.

„Ena med 30.000“, Slovenec (Ljubljana), br. 88, 18. 4. 1929., 3.

„Iz domače kronike“, Slovenski narod (Ljubljana), br. 109, 16. 5. 1926., 1.

„Izven meja Slovenije“, Slovenski gospodar (Maribor), br. 21, 22. 5. 1940., 2.

„Naša dekleta“, Ljudska pravica (Lendava), br. 6, 14. 12. 1934., 2.

„Obup slovenske služkinje v Zagrebu“, Mariborski večernik „Jutra“(Maribor), br. 83, 12. 4. 1934., 2.

„Obup slovenske služkinje v Zagrebu“, Slovenski narod (Ljubljana), br. 82, 27. 8. 1936., 3.

„Ognjišče dekliško zavetišče v Zagrebu“, Slovenec (Ljubljana), br. 64a, 17. 3. 1940., 5.

„Po domovini“, Bogoljub (Ljubljana), 20/1922., br. 4, 90-91.

„Samomor slovenske služkinje“, Domovina (Ljubljana), br. 1, 5. 1. 1933., 7.

„Samomor slovenske služkinje“, Jutro (Ljubljana), br. 82, 10. 4. 1931., 2.

„Samomor slovenske služkinje“, Jutro (Ljubljana), br. 100, 30. 4. 1933., 6.

„Samomor slovenske služkinje v Zagrebu, Domovina (Ljubljana), br. 22, 2. 7. 1938., 6.

„Samomor slovenske služkinje v Zagrebu“, Slovenec (Ljubljana), br. 66, 21. 3. 1926., 4.

„Samomor slovenske služkinje v Zagrebu“, Slovenski narod (Ljubljana), br. 39, 24. 4. 1933., 3.

„Slovenci v Zagreb! Rojaki! Slovenci!“, Domoljub (Ljubljana), br. 45, 11. 11. 1921., 3.

„Slovenko povozil vlak“, Jutro (Ljubljana), br. 233, 9. 10. 1926., 3.

„Slovenska Marijina družba v Zagrebu ob 15 letnici“, Slovenec (Zagreb), br. 97, 28. 4. 1940., 7.

„Slovenske služkinje v Zagrebu“, Slovenski dom (Ljubljana), br. 20, 25. 1. 1939., 3.

„Ta nesrečna ljubezen“, Jutro (Ljubljana), br. 228, 30. 9. 1937., 4.

„Tragedija slovenske služkinje v Zagrebu“, Slovenski narod (Ljubljana), br. 29, 28. 2. 1935., 2.

„Zagoneten samomor pridne služkinje“, Mariborski večernik „Jutra“ (Maribor), br. 135, 16. 6. 1934., 2.

„Žaloigra mlade služkinje“, Domovina (Ljubljana), br. 15, 13. 4. 1933., 12.

„Žaloigra slovenske služkinje“, Domovina (Ljubljana), br. 4, 26. 1. 1933., 6.

„Žalostna usoda slovenskih deklet“, Mariborski večernik „Jutra“(Maribor), br. 93, 24. 4. 1929., 2.

\section{Literatura}

Sanja Cukut Krilić, Spol in migracija: izkušnje žensk kot akterk migracij, Ljubljana 2009.

Marjan DrnovšEK, „Amerika: raj za ženske“, Zgodovina za vse, 4/1997., br. 1, 20-30.

Irena Gantar Godina, „Slovenske izobraženke v Pragi“, Dve domovini: razprave o izseljenstvu, 16/2002., 186-189.

Franc Grivec, Alojz Odar i Kazimir Zakrajšek, Če greš na tuje, Ljubljana 1934.

Dunja JAKOPOvić, Kućna služinčad u gradu Zagrebu dvadesetih godina 20. stoljeća, diplomski rad, Zagreb 2018.

Mirjana JuRIĆ, „Zagreb u Prvom svjetskom ratu: povijesne novine kao izvor za istraživanje socijalne povijesti“" Libellarium: časopis za povijest pisane riječi, knjige i baštinskih ustanova, 2/2009., br. 2, 121-144.

Janez Kalan, „Slovenci med Hrvati in katoličani v Belgradu“, Bogoljub, 20/1922., br. 12, 271-275.

Marija KNEz, Taku je blo anbot: KD Šavrini in anka Šavrinke, Gračišče 2011. 
Bogdan Kolar, „Delo slovenskih duhovnikov med Slovenci v Zagrebu med obema vojnama“, u: Slovenci v Hrvaški (ur. Vera Kržišnik-Bukić), Zagreb 1995., 115-131.

Mira Kolar-Dimitrijević, Radni slojevi Zagreba od 1918. do 1931., Zagreb 1973.

Daša Koprivec, Dediščina aleksandrink in spomini njihovih potomcev, Ljubljana 2013.

Vera KRŽIŠNıK-Bukıć, „Okvirni pregled poteka, vzrokov in pomena izseljevanja Slovencev na Hrvaškoj", Razprave in gradivo: revija za narodnostna vprašanja, 29-30/1994. - 1995., 85-93.

Špela Ledinek Lozej i Nataša Rogelja, Potepanja po poteh Šavrinke Marije, Ljubljana 2000.

Jernej Mlekuž, „Izbrani vidiki zaposlovanja beneških deklet v gospodinjstvih italijanskih mest: tiha grenko-sladka, nikoli povsem izrečena in slišana zgodba", Dve domovini: razprave o izseljenstvu, 19/2004., 141-164.

Jernej Mlekuž, „Življenjska pripoved migrantke Luise: prispevek za 'drugačno’ družbeno geografijo“, Geografski vestnik, 76/2001., br. 1, 37-52.

Mirjana Morokvašıć, „Feminizacija migracija?“, Stanovništvo, 2/2010., 25-52.

Mirjana Morokvašıć, „Gendering Migration“, Migracije i etničke teme, 30/2014., br. 3, 355-378.

Katarina PAJNič, „Ekonomski položaj in demografska struktura Slovencev na Hrvaškem: včeraj, danes, jutri“, Razprave in gradivo: revija za narodnostna vprašanja, 80/2018., 65-88.

Mateja Raten, „Slovenske hišne pomočnice v Beogradu pod okriljem Katoliške cerkve in (razpuščene) Slovenske ljudske stranke v tridesetih letih 20. stoletja“, Zgodovinski časopis, 68/2014., br. 3-4, 372-387.

Barbara Riman, „Slovenska društva u Hrvatskoj između dva svjetska rata“, Časopis za suvremenu povijest, 46/2014., br. 1, 101-130.

Barbara Riman, „Slovenske dekle na radu u Hrvatskoj krajem 19. i početkom 20. stoljeća“, u: $U z$ duž i poprijeko. Brak, zakon i gradanstvo u povijesnoj i suvremenoj perspektivi (ur. Anita Dremel i dr.), Zagreb 2015., 125-134.

Darja SкRT, Aleksandrinke, Ljubljana 2014.

„Slovenska dekleta v Zagrebu“, Vigrede, 17/1939., br. 10, 394.

Agneza Szabo, Socijalna struktura Slovenaca u Kraljevini Hrvatskoj i Slavoniji između 1880. i 1910. godine“, u: Slovenci v Hrvaški (ur. Vera Kržišnik-Bukić), Zagreb 1995., 85-105.

Filip ŠKILJAN, „Pisanja slovenskoga časopisa Odmev 1932. i 1933.“, Studia lexicographica: časopis za leksikografiju i enciklopedistiku, 4/2010., br. 1 (6), 139-162.

Stazica Zorn i Inga Miklavčič-Brezigar (ur.), Aleksandrinke iz Renč, Ljubljana 2015.

\section{Mrežna stranica}

Državni zavod za statistiku, Popis stanovništva 2011. (https://www.dzs.hr/) 